\title{
A INTERAÇÃO DIALÓGICA EM AMBIENTES VIRTUAIS DE CURSOS A DISTÂNCIA
}

\section{DIALOGICAL INTERACTION IN THE VIRTUAL ENVIRONMENTS OF DISTANCE COURSES}

\author{
Fabia Magali Santos Vieira* \\ Maria Clara Maciel de A. Ribeiro" \\ Ilmar Duarte Fonseca Aguiar"**
}

Resumo: O presente artigo apresenta resultados parciais da pesquisa Observatório Tecnologias Digitais e Educação, desenvolvida na Universidade Estadual de Montes Claros (Unimontes), que teve como objetivo discutir a interação dialógica nos ambientes virtuais de um curso de graduação a distância. Foram analisadas 285 mensagens postadas em Fóruns de Discussão do Ambiente Virtual de Aprendizagem, considerando as categorias comunicação, participação e colaboração. Os dados foram coletados e analisados segundo uma abordagem dialético-histórica e indicam que, apesar dos avanços da Educação Aberta e a Distância, as práticas ainda são convencionais e monológicas, centradas no professor. Assim, há uma tendência de se reproduzir no virtual, com uma nova roupagem, práticas convencionais e ultrapassadas, centradas no papel ativo do professor.

Palavras-chave: Educação a distância; interação dialógica; colaboração; participação.

Aвstrat: This article presents partial results from the research "Digital Technologies and Education Observatory" conducted at the State University of Montes Claros (Unimontes), that aimed to analyze the dialogical interaction in the virtual environments of a distance graduation course. We analyzed 285 messages posted at the Virtual Learning Environment Discussion Forum, considering the following categories: communication, participation and collaboration. The data were collected and analyzed based on a historical-dialectical approach and they indicate that despite the advances of the Open and Distance Education, the practices are still conventional and monological, centered in the teacher. Thus, there is a tendency to reproduce, in

\footnotetext{
* Doutora em Educação pela UnB e pesquisadora e professora da graduação e do Programa de Pós-Graduação em Educação da Universidade Estadual de Montes Claros (Unimontes). E-mail: fabiamsv@gmail.com.

** Doutora em Estudos Linguísticos pela UFMG e pesquisadora e professora da graduação e do Programa de Pós-Graduação em Educação da Universidade Estadual de Montes Claros (Unimontes). E-mail: mclaramaciel@hotmail.com.

***:Graduada em Pedagogia pela Universidade Estadual de Montes Claros (Unimontes). E-mail: ilmardf@hotmail.com.
} 
the virtual environment, with a new design, conventional and outdated practices, centered in the active role of the teacher.

KeYwords: Distance education; Dialogic interaction; Collaboration; Participation.

\section{INTRODUÇÃo}

O ciberespaço (ambiente surgido com o advento da internet) tem sido utilizado pela educação como um lócus de ensino-aprendizagem por oferecer, além de novas formas de comunicação, meios dinâmicos para coordenar e aliar interações e gestão de conhecimento. Para Vieira (2003), os grandes entusiastas dessa utilização, como Levy (2010), acreditam que o espaço virtual seja um ambiente móvel de interações entre conhecimentos e sujeitos com capacidade de criar comunidades de aprendizagem inovadoras. Nessas comunidades, os participantes assumem como objetivo a negociação permanente da ordem estabelecida - seja da linguagem, seja do papel de cada um ou mesmo da definição de objetivos - visto que os atos são continuamente coordenados e avaliados em tempo real, segundo critérios apontados pela própria comunidade. Partindo desse pressuposto, temos assistido cada vez mais ao desenvolvimento de ambientes de ensino-aprendizagem que utilizam de Tecnologias Digitais de Informação e Comunicação (TDIC) para mediatizar interações pedagógicas no ciberespaço, sobretudo neste momento de isolamento social proporcionado pela pandemia de Covid-19. ${ }^{1}$

As TDIC oferecem possibilidades inéditas de interação mediatizada entre professor/ estudante e estudante/estudante, assim como de interatividade com materiais digitais com grande variedade. As técnicas de interação mediatizada criadas pelas redes telemáticas (e-mail, grupos de discussão, redes e mídias sociais) apresentam vantagens significativas, pois permitem combinar a flexibilidade da interação humana com a independência no tempo e no espaço, sem por isso perder velocidade (BELLONI, 2015). Dessa forma, a educação online, realizada essencialmente no ciberespaço e que utiliza técnicas de interação mediatizada, tem sido uma alternativa de educação a distância, no sentido de proporcionar a interatividade, colaboração e aprendizagem de estudantes e professores por meio da internet. Essa possibilidade enriquece notavelmente a interatividade entre professores e estudantes e entre os próprios estudantes, flexibilizando e personalizando a educação, permitindo, assim, a introdução de estratégias didáticas, anteriormente impossíveis, devido a limitações impostas pelos meios de comunicação disponíveis.

Segundo Gur-Ze'ev (2019), os otimistas do ciberespaço vislumbram a criação, neste espaço, de uma sociedade igualitária e democrática na qual os indivíduos e grupos teriam a

\footnotetext{
${ }^{1}$ Este artigo foi produzido e publicado em 2020 , num momento em que o mundo passou a experimentar mais de perto o uso disseminado de TDIC na educação, em função da pandemia de Covid-19, que impôs regras de isolamento social como estratégia de controle da patologia.
} 
força de participar de uma verdadeira "democracia radical". Convém, no entanto, delimitar horizontes e fronteiras das possibilidades educacionais no ciberespaço. Vieira (2003) e GurZe'ev (2002) alertam para a necessidade de aprofundar a própria possibilidade de uma teoria crítica e de uma educação emancipadora neste espaço. Para esse autor, a leitura não crítica vê o ciberespaço como um espaço onde a identidade apresenta-se isenta de gênero e etnia, permitindo aos internautas navegarem livres das amarras biológicas ou sócio-culturais, formando comunidades virtuais solidárias e uma possível democracia virtual.

As possibilidades de uma interação dialógica no ciberespaço entre usuários, imagem, texto e conhecimentos que permitem a participação, a intervenção, a colaboração, a bidirecionalidade e a multiplicidade de conexões podem gerar a ilusão de um verdadeiro ambiente democrático. Segundo Soares (2017), essa ilusão se desmorona quando se constata que, ao diversificar os meios e centralizar os fins, esse modelo reproduz na comunicação uma das características do sistema capitalista de fortalecimento das desigualdades sociais.

Diante disso, para além da educação, Vieira (2003) informa que, embora o ciberespaço tenha provocado algumas transformações significativas, principalmente no que se refere a participações individuais dos cidadãos na vida pública, inúmeros programas, aplicativos e redes sociais concretizam uma experiência de participação individualizada que oferece aos sujeitos uma falsa impressão de liberdade e de esteamento num espaço democrático. Contudo, muitas vezes, tais recursos diluem as fronteiras entre o pessoal e o impessoal, o conhecido e o anônimo, a opinião e a pós-verdade. Assim, posicionamentos muitas vezes se tornam monólogos: muitos querem se fazer ouvir, emitir opiniões, mas sem ouvir aquele que está na outra ponta, não possibilitando, dessa maneira, a manifestação de uma interação dialógica, fazendo prevalecer efeitos monológicos.

A educação não passa incólume a esse fenômeno. Para Vieira (2003), ao buscar diferentes estratégias para atingir os objetivos de preparar para o exercício da cidadania e produzir conhecimento, a universidade tem lançado mão da educação online, realizada no espaço da internet (o ciberespaço) para promover cursos de atualização e formação dos profissionais das mais diferentes áreas. Contudo, é necessário avaliar as reais possibilidades de práticas democráticas e dialógicas neste espaço, principalmente da relação entre sujeitos e conhecimentos, para que a universidade possa realmente cumprir seu papel, promover cidadania e criar condições para que todos possam dialogar e intervir na realidade.

Isso posto, o problema que o projeto de pesquisa Observatório Tecnologias Digitais e Educação, realizado na Universidade Estadual de Montes Claros (Unimontes), está investigando é até que ponto é possível promover, de fato, uma interação dialógica de qualidade entre sujeitos e conhecimentos em ambientes de aprendizagem disponíveis no ciberespaço de duas disciplinas selecionadas para a pesquisa. Para tanto, refletimos sobre os fatores que permitem, dificultam ou impedem essa interação, considerando-se as categorias comunicação, participação e colaboração. 
Para responder essas questões, estruturamos este artigo em quatro seções. A primeira discute a democracia enquanto categoria teórico-reflexiva. A segunda aborda a interação dialógica tanto numa perspectiva ampla quanto numa perspectiva cibernética. A terceira seção contempla os procedimentos metodológicos da pesquisa, enquanto a última, por fim, apresenta a análise dos dados, encaminhando o artigo para suas conclusões finais.

\section{DEMOCRACIA: ALGUMAS REFLEXõES TEÓRICAS}

A palavra democracia foi usada pela primeira vez no século V A.C. pelo historiador Heródoto, combinando as palavras gregas demos (povo) e kratein (governar). Assim, na Antiguidade do período pós-socrático, a tarefa de pensar a sociedade deixa de ser algo restrito a alguns privilegiados, como rabinos, sacerdotes e cortesãos e passa a ser algo pertencente a todos os cidadãos que queiram discutir questões relacionadas ao bem comum, publicamente, fazendo com que o cidadão participe ativamente da vida pública da sociedade.

Nesse regime criado pelos gregos, denominado democracia, prevalecia a formação e a confrontação de opiniões comuns. A refutação de opiniões diferentes era aceita e legítima, constituindo a própria essência da vida pública, o que valorizava as decisões coletivas, visando à criação de seres humanos que tivessem uma preocupação com a coletividade. Assim, ser cidadão na Grécia era reivindicar ativamente a participação na vida pública e nos negócios comuns.

A concepção de democracia grega, que valorizava a vida em comum e a participação ativa do cidadão na vida pública, está muito distante da concepção de democracia moderna, defendida pela teoria liberal burguesa, a partir do século XIX. Para Castoriadis (1992), os filósofos clássicos chamariam de regimes de oligarquia os regimes que hoje se afirmam democráticos, pelo fato de que somente uma estreita camada da sociedade domina e governa, sendo ratificada a cada período de eleição.

Do ponto de vista conceitual, a democracia não se define pela participação, nem pelo consenso, mas pelo respeito às liberdades e às diversidades de crenças, origens, opiniões e projetos. O que define a democracia hoje não é um conjunto de garantias institucionais, "mas o respeito pelos projetos coletivos, que combinam a afirmação de uma liberdade pessoal com o direito de identificação com uma coletividade social, nacional ou religiosa" (TOURAINE, 2007, p. 26).

Para Araújo (2000), a democracia deve valorizar o princípio da liberdade de ação dos sujeitos, sendo a democracia o espaço onde se estabelece o conflito, as tensões, as negociações, o respeito à pluralidade de interesses, de cooperação e de compromisso com outros atores sociais, individuais ou coletivos, no campo das decisões.

Do ponto de vista de Freire (2013a), a base da democracia é o diálogo corajoso com o povo, principalmente com as camadas populares. Sua legitimidade está neste diálogo, não no engodo ou na manipulação. Um regime verdadeiramente democrático incentiva a expressão 
e a participação efetiva de todos no poder. O diálogo, como exigência radical da democracia, responde, assim, a outra exigência radical: o direito e acesso à comunicação e à informação. Obstaculizar a comunicação é reificar os sujeitos, reduzindo-os a objetos, notadamente, tarefa e objetivo de opressores, não de democratas. Cumpre, assim, compreender melhor em que medida a interação dialógica pode ser vista como tributo da democracia.

\section{A interação dialógica COMO ATRIBUto DEMOCRÁtico}

Ao se propor a discutir a questão da interação humana, Berlo, citado por Primo e Cassol (1999, p. 8), identifica que "existe uma relação de interdependência na interação, onde cada agente depende do outro, isto é, cada qual influencia o outro". Essa interdependência varia em grau, em qualidade e de contexto para contexto, porém, cumpre perceber a limitação de se entender a interação apenas como ação e reação. Para o autor, os termos "ação" e "reação" rejeitam o conceito de processo, pois indicam o começo da comunicação (o ato) e um segundo acontecimento (reação), acontecimentos subsequentes e um fim, não realizando um tipo de interdependência dinâmica que se compreende no processo de comunicação.

Na perspectiva histórico-cultural do desenvolvimento humano, o processo de conhecimento é concebido como produção simbólica e material que tem lugar na dinâmica interativa. Tal movimento interativo implica uma relação sujeito-objeto- outros. Isso significa que é por meio do outro que o sujeito estabelece relações com os objetos de conhecimento, ou seja, que a elaboração cognitiva se funda na relação com o outro. Assim, a constituição do sujeito, com seus conhecimentos e formas de ação, deve ser entendida na sua relação com o outro, no espaço da intersubjetividade.

Vygotsky (2008) defende que as ideias não ocorrem por si mesmas, mas surgem das atividades, e as atividades se definem como tais na inter-relação entre indivíduos e meio. Ele considera que o indivíduo é um ser social que constrói sua individualidade a partir das interações que se estabelecem entre os indivíduos mediados pela cultura. Para ele, a relação do ser humano com o meio é condição para que se constitua como sujeito.

Na perspectiva sócio-histórica, a comunicação humana se dá essencialmente por meio da linguagem, portanto ela tem um papel fundamental no desenvolvimento do sujeito. A linguagem amplia o universo do indivíduo, uma vez que o liberta do mundo perceptual imediato. Além disso, uma vez internalizada a linguagem, transforma-se num instrumento intrapsíquico de regulação da própria ação e da ação do outro.

Segundo Moraes, Fiorentini e Dias (2003), Bakhtin (2006) e Freire (2013a) concebem a linguagem como dialógica, pois as idéias sobre o homem e a vida são marcadas pelo princípio dialógico que constitui a linguagem humana. Para as referidas autoras, o princípio que vigora em cada indivíduo dialogante é que sua fala se realiza e cria sentido se pensada a partir de sua relação com o outro. São os outros que falam e é a eles que o indivíduo fala. Assim, falar é 
tanto responder quanto dirigir perguntas, mesmo que essas cheguem ao indivíduo com outro sentido e que ele não responda exatamente o que foi perguntado, acontecendo o mesmo com as perguntas que ele dirige aos outros. Assim, os elementos fundamentais do dialogismo, interação e interatividade, surgem desta intersecção entre os sujeitos dialogantes em uma situação de interlocução intersubjetiva.

Isso significa redimensionar o processo de comunicação ao superar a unidirecionalidade da mensagem, modificando os papéis de emissores e receptores, que passam a ser co autores/criadores. Nessa perspectiva, o inter-agir deixa de ser um simples enviar e responder mensagens; emissor e receptor passam a fazer parte de um processo de relações interligadas por fios dialógicos que trocam, completam, perguntam, respondem em um processo dinâmico de construção e desconstrução entre as diferentes vozes, para a negociação dos sentidos e para a construção coletiva de discursos.

Primo e Cassol (1999) sugerem uma forma de percepção da interação que inclui as relações que se dão de forma mútua e negociada, chamada por ele de interação mútua. Em se tratando de uma interação mediatizada pelas tecnologias da informação e comunicação que não deseja depositar a ênfase nem na máquina nem no agente humano, o foco de análise volta-se à própria interação, no que acontece entre os interagentes.

Para este autor, entre os interagentes, emerge um terceiro fator desconsiderado por muitos paradigmas, que é a relação em si, que vai sendo definida durante o processo pelos participantes da interação. Nesse sentido, entende-se interação como "ação entre", isto é, recusa-se a valorização do chamado "emissor" ou do "receptor" para se deslocar a investigação para o que ocorre entre os interagentes, observando a interação, as ações entre eles, as mediações, considerando as influências do contexto na interação. Em se tratando de uma interação mediada pelas TDIC, como na educação online, deve-se salientar as relações recíprocas que ocorrem entre os sujeitos, mediadas pelo computador, valorizando a construção entre os interagentes: uma interação não-previsível e de conteúdos que emergem durante a relação (que não estão prontos a priori).

\section{Pressupostos para uma interação dialógica}

Para entender o diálogo como fenômeno humano, Freire (2013a) alerta para a importância da palavra como sua essência. Na palavra, existem duas dimensões, ação e reflexão em constante interação, uma práxis. Por isso, toda palavra verdadeira deve transformar o mundo.

A palavra inautêntica, esgotada da sua dimensão ação/reflexão, pode ser alienada e alienante ou se converter em ativismo, negando a práxis verdadeira e impossibilitando o diálogo.

Para Freire (2013b), a palavra verdadeira, que é trabalho, práxis, significa transformar o mundo e deve ser privilégio de todos os homens; por isso ninguém pode dizer a palavra 
sozinho, mas deve dizê-la para outros. O encontro dos homens mediatizados pelo mundo, para pronunciá-lo é no que consiste o diálogo. Pronunciando o mundo, os homens o transformam.

Não é possível o diálogo entre os que querem a pronúncia do mundo e os que não querem; entre os que negam aos demais o direito de dizer a palavra e os que se acham negados deste direito. Para que o diálogo se realize, é preciso, primeiro, que todos reconquistem esse direito.

O diálogo não deve ser reduzido ao ato de depositar idéias de um sujeito no outro, a uma simples troca de idéias, a uma discussão polêmica, entre sujeitos que não aspiram a se comprometer com a pronúncia do mundo, nem com a verdade, nem impor a suas idéias e verdades. Deve, ao contrário, ser o encontro em que se solidarizam o refletir e o agir de seus sujeitos endereçados ao mundo a ser transformado.

O diálogo também se faz numa relação horizontal de confiança de um polo a outro. A confiança vai fazendo dos sujeitos dialógicos companheiros na pronúncia do mundo. A confiança implica no testemunho que o sujeito dá aos outros de suas reais e concretas intenções. Não pode existir, se a palavra, descaracterizada, não coincide com os atos. "Falar, por exemplo, em democracia e silenciar o povo é uma farsa. Falar em humanismo e negar os homens é uma mentira" (FREIRE, 2013a, p. 96).

Somente o diálogo crítico é gerado a partir de um pensar crítico. Sem ele, não há comunicação e, consequentemente, não haverá educação. Numa concepção de educação como prática de liberdade, a interação dialógica começa não quando o educador-educando se encontra com os educandos-educadores em uma situação pedagógica, mas antes, quando aquele se pergunta em torno do que vai dialogar com estes. Para o educador-educando dialógico, problematizador, o conteúdo, o assunto do diálogo "não é uma doação ou uma imposição - um conjunto de informes a ser depositado nos educandos, mas a devolução organizada, sistematizada e acrescentada ao povo, daqueles elementos que este lhe entregou de forma inestruturada" (FREIRE, 2013a, p. 98).

Partimos da tese de Freire (2013a, p. 98) de que "a educação autêntica não se faz de "A" para "B" ou de "A" sobre "B", mas de "A" com "B", mediatizados pelo mundo", mundo este que impressiona e desafia os homens, originando diferentes visões e pontos de vista. Visões impregnadas de anseios, de dúvidas, de esperanças que explicitam temas significativos que definirão o que deverá ser discutido.

O papel do revolucionário não é falar ao povo sobre sua visão do mundo, ou tentar impô-la, mas dialogar com ele sobre as diferentes visões. O revolucionário tem que estar convencido de que sua visão do mundo manifesta nas várias formas de sua ação reflete a sua situação no mundo em que constitui. A ação educativa e política não pode prescindir do conhecimento crítico dessa situação, sob pena de se fazer "bancária" ou de pregar no deserto.

Para que haja comunicação eficiente, é preciso que o sujeito seja capaz de conhecer as condições estruturais em que o pensar e a linguagem do povo dialeticamente se constituem. É 
na realidade mediatizadora, na consciência de todos os envolvidos, que se busca o que deverá ser discutido. Para Freire (2013b), é no momento da busca que se estabelece o diálogo como prática de liberdade.

Numa concepção libertadora, "os homens devem se sentir sujeitos de seu pensar, discutindo seu pensar, sua própria visão do mundo, manifestada implícita ou explicitamente, nas suas sugestões e nas de seus companheiros" (FREIRE, 2013a, p. 141).

\section{A INTERAÇão diaLÓGica No CiberesPaço}

Partindo dos pressupostos discutidos para que a educação online possa atingir seus objetivos, deve-se superar qualquer tentativa de homogeneizar pensamentos ou transmitir informações, como faz a educação bancária/positivista; deve-se possibilitar a interação entre todos os envolvidos, "A" com "B", mediatizados pelo mundo", segundo uma perspectiva dialética dialógica, de inspiração freiriana. Para que o ciberespaço possa ser verdadeiramente utilizado pela educação online como um espaço democrático, este deve possibilitar o diálogo, em uma constante interação ação/reflexão e incentivar a expressão e participação de todos os envolvidos, no sentido de transformar a realidade. Deve ser um espaço onde os sujeitos possam interagir uns com os outros, ou seja, possam manifestar, refletir, discutir, se posicionar, colaborar, negociar, partilhar informações e auxiliar na construção de conhecimentos. Enfim, um espaço onde não haja dominação de uns sob os outros, mas solidariedade na construção de uma sociedade mais justa e igualitária. E quando houver, nessa interação, uma intenção de dominação, esta deve ser evidenciada, dialogada e superada, e não hipocritamente acobertada.

A nosso ver, no ciberespaço, o conceito de interação deve vislumbrar a possibilidade de uma integração complexa, múltipla, dialógica entre sujeitos, conhecimento e tecnologia. Pelo fato das tecnologias propiciarem o diálogo entre emissor e receptor, possibilitando que ambos interfiram na mensagem, a interação deve ser considerada como um processo que rompe com a linearidade e com a separação entre emissão e a recepção da informação, possibilitando a participação, a intervenção de todos, a bidirecionalidade, a multiplicidade de conexões e a criação de novos significados. Ou seja, deve possibilitar o dialogismo, entendido este conceito a partir do marco conceitual de Freire e Bakhtin.

Nesta perspectiva, entendemos por interação dialógica as relações de comunicação, de diálogo, que se dão de forma negociada em um determinado contexto social culturalmente construído, que tem como objetivo possibilitar as ações interdependentes dos sujeitos, de solidariedade, reflexão e ação endereçadas ao mundo a ser vivido e transformado. Essas ações se dão por cooperação, permutabilidade, predisposição para falar, ouvir, argumentar, participar e intervir em direção a uma bidirecionalidade - fusão emissão-recepção. Assim, o centro da interlocução 
não está no emissor ou no receptor, mas no espaço criado entre ambos como consciências empenhadas em um entendimento simultâneo: "cada palavra é resultado de um diálogo ininterrupto, numa relação de força entre eu e o outro - vozes que representam discursos sociais e consciências diferenciadas" (MORAES; FIORENTINI; DIAS, 2003, p. 38).

A nosso ver, a interação que tem como objetivo promover o encontro dos homens mediatizados pelo mundo para transformá-lo, pode contribuir para a formação da cidadania ao possibilitar que o sujeito saia da passividade da recepção e se engaje na tessitura de uma rede, aprendendo com o diferente, negociando, ligando o que está separado, lidando com as múltiplas informações, processando e transformando essas informações em conhecimento para buscar a libertação dos homens.

Segundo Moraes, Fiorentini, Dias (2003), no campo educacional, a comunicação tem apresentado um caráter linear, impositivo e monológico, em que as partes são dicotomizadas entre emissor (professor) e receptor (aluno). Nesse modelo, o emissor se restringe a enviar a mensagem ao receptor, que, por sua vez, a recebe de uma forma passiva e acrítica. O diálogo se restringe a um discurso monológico, pronto, não existindo espaço de interação para a coconstrução e a língua passa a ser um instrumento de reprodução do sistema vigente.

As autoras afirmam que Freire criticou esse monologismo de comunicação ao afirmar que ensinar exige criticidade e respeito à autonomia do ser educando. Não é simplesmente transmitir conhecimentos, mas criar as possibilidades para a sua produção ou construção.

A relação pedagógica na educação online é uma relação entre seres humanos imersos em uma determinada cultura, por isso mesmo transformadores dela. Ademais, a educação online também deve possibilitar o desenvolvimento da autonomia intelectual do estudante, entendendo, por autonomia, "o desenvolvimento das capacidades de pesquisar, organizar e de pensar de forma crítica e independente” (PONTES, 1999, p. 416).

Como a educação online é geralmente voltada para atender à demanda de adultos, é necessário dedicar atenção à diversidade de interesse, motivações, necessidades e habilidades dos estudantes/adultos. Nela, os estudantes buscam flexibilidade, liberdade pessoal e, ao mesmo tempo, necessitam da colaboração do grupo e do relacionamento social. Assim, a educação online deve ter, como objetivo, além de mediar a comunicação, criar condições para que todos os atores envolvidos possam estabelecer um diálogo crítico e criativo com a realidade, o desenvolvimento de estratégias de aprendizagem para produção de conhecimentos e promoção da cidadania, culminando não só na elaboração do conhecimento e no desenvolvimento de capacidades de intervenção, mas na libertação dos homens e transformação da realidade.

Nas relações comuns e universais, a interação é complexa e exige o concurso de fundamentos filosóficos, sociológicos, psicológicos, linguísticos, semióticos, históricos e antropológicos. Enfim, a interação depende da cultura do grupo. A interação, no ciberespaço, entre 
pessoas com diferentes princípios de vida, costumes, habilidades, conhecimentos, preconceitos, limitações, escolaridade e objetivos, isto é, com sua cultura grupal/social é complexa e complicada, fazendo surgir muitas vezes conflitos, bloqueios, incompreensões, objeções a partir de mensagens duplas, paradoxais, falsas, contraditórias ou incompreensíveis.

A partir da constatação do exposto e dos referenciais teóricos utilizados, sugere-se uma forma mais ampla de percepção da interação, que inclui as relações que se dão de forma mútua e negociada e se estabelecem entre os sujeitos e seus contextos histórico-sociais com o mundo da cultura. Não se deve depositar a importância somente sobre o sujeito, mas deve-se, também, valorizar a própria interação, o que acontece entre os interagentes. Trata-se, portanto, de valorizar a qualidade da relação que faz emergir a ação entre os sujeitos e as possibilidades de uma interação dialógica no ciberespaço, visando à construção do conhecimento, da cidadania e, principalmente, de uma sociedade mais democrática.

\section{COMUNICAÇÃO, PARTICIPAÇão E COLABORAÇão: PILARES DO EDIFíCIO DA DEMOCRACIA}

Considerando que o conceito de democracia implica num princípio ético de igualdade, liberdade e fraternidade, Bobbio (2017) afirma que o liberalismo, vigente em nossa sociedade, utiliza-se dos mais variados e sofisticados disfarces e artifícios para impor o totalitarismo, empregando inúmeros recursos como fachada democrática, sendo o ciberespaço, um deles. Sob o artifício de possibilitar a busca de informações, trocar experiências com pessoas ou grupos de todas as tendências, em qualquer parte do mundo e de estar sempre acessível, o ciberespaço cria uma sensação realista de aldeia global, dando a esse espaço uma aparência democrática.

Alguns teóricos educacionais nos alertam que a educação a distância e o ciberespaço aumentam a ilusão de participação democrática e, com o aperfeiçoamento tecnológico, o consumismo, as atitudes autoritárias disfarçadas, a homogeneização de pensamentos, aprofundam o totalitarismo do sistema, reforçando o globalismo. Contudo, alguns teóricos da pedagogia crítica, como Peters (2000), Kellner (2008), Gur-Ze'ev (2002) e Moraes (2001), ressaltam as contradições e as possibilidades emancipatórias dessa mídia.

Freire (2013) afirma que o mundo humano é um mundo de comunicação. "Corpo consciente (consciência intencionada ao mundo, à realidade), o homem atua, pensa e fala sobre sua realidade, que é a mediação entre ele e outros homens, que também atuam, pensam e falam" (FREIRE, 2013a, p. 66). Nessa perspectiva, além do sujeito pensante, do objeto, há, como exigência, a presença de outro sujeito pensante, representado na expressão de companhia, cuja ação incidente no objeto seria, por isso mesmo, co-participada.

Nessa perspectiva, a comunicação implica numa reciprocidade que não é rompida e a compreensão do pensamento deve-se dar em sua dupla função: cognoscitiva e comunicativa. Comunicar é comunicar-se em torno do significante/significado. Nessa perspectiva, Freire 
(2013b) afirma que, na comunicação, não há sujeitos passivos, os sujeitos co-intencionados ao objeto de seu pensar comunicam entre si seu conteúdo. Logo, para que a relação comunicativa se efetive, é necessário que se estabeleça, entre os sujeitos interlocutores, a compreensão em torno da significação do signo.

Almeida (2001) afirma que, à medida que o homem interage com o contexto e com os objetos aí existentes, ele atua sobre esses objetos, retira informações que lhe são significativas, identifica-os e os incorpora à sua rede, transformando o meio e sendo transformado por ele. Nesse processo, a criação de redes de conhecimento, para essa autora, por meio do uso da tecnologia, traz subjacente a provisoriedade e a transitoriedade do conhecimento, cujos conceitos articulados constituem os nós dessa rede, flexível e sempre aberta a novas conexões, as quais favorecem compreender "os problemas globais e fundamentais para neles inserir os conhecimentos parciais e locais” (ALMEIDA, 2001, p. 1).

No bojo dessa discussão, podemos concluir que, nas redes utilizadas como ambientes de aprendizagem, em que se objetiva a troca democrática de idéias, de saberes, de pontos de vista sobre um tema previamente escolhido e se predomina o respeito mútuo, configurando um alto nível de socialização, pode surgir a colaboração e a participação efetiva.

Serrão (2001) apresenta uma distinção entre aprendizagem colaborativa ou cooperativa, explicando que a colaboração implica em um processo mais aberto, em que os integrantes do grupo interagem para atingir um objetivo comum, enquanto que, na cooperação, existe uma organização maior do grupo, com um maior enfoque no controle da situação pelo professor. Enquanto a colaboração coloca a ênfase na interação entre os sujeitos participantes com vistas a um processo de criação compartilhado, a cooperação, em ambientes telemáticos, focaliza mais a organização e o gerenciamento de informações, enfatiza as relações de trabalho e não a construção de algo em conjunto. Assim sendo, ao criar-se um ambiente de aprendizagem colaborativa apoiado por computador, é necessário ter presente que a colaboração deve ser fomentada e construída, razão pela qual é fundamental uma análise criteriosa das propostas e estratégias que serão empregadas, de forma a utilizar, prioritariamente, aquelas que promovam a colaboração.

Kellner (2008, p. 5) defende que "aprender é desenvolver habilidades de interagir inteligentemente com o ambiente e com os seres humanos e exige atmosferas sociais e conversações vibrantes. A educação exige o fazer e é ganha na prática e na interação social.”

Interagir significa agir mutuamente e isso diz respeito a duas ou mais pessoas ou objetos. Segundo teóricos como Primo e Cassol (1999), a interação pode ser ativa ou reativa (esse é o caso, por exemplo, dos espectadores de TV, que não podem modificar os programas, que já lhes chegam prontos e acabados). Interagir ativamente (é o que muitos denominam interatividade) significa ter chance de modificar, de alguma forma, o que lhe é oferecido e, nesse caso, o leitor, ouvinte ou espectador passa a ser coautor. 
Nesse sentido, Perrenoud (2000, p. 139) afirma que o papel do professor redefine-se: "mais do que ensinar, trata-se de fazer aprender [...], concentrando-se na criação, na gestão e na regulação das situações de aprendizagem”. Para Almeida (2001), essa mediação propicia a aprendizagem significativa aos grupos e a cada aluno. Dessa forma, considera que se pode mobilizar os acadêmicos para a investigação e a problematização, alicerçados no desenvolvimento de projetos, solução de problemas, reflexões individuais e coletivas, nos quais a interação e a colaboração subsidiam a representação hipertextual do conhecimento.

A partir dessas reflexões, podemos concluir que rede colaborativa de aprendizagem é um sistema aberto, dinâmico e flexível, no qual os integrantes do grupo interagem para atingirem um objetivo comum: construírem o conhecimento. Nesse processo, os integrantes do grupo se comunicam, participam, discutem, argumentam, reavaliam e ressignificam os seus diferentes pontos de vista. Essa colaboração supõe adesão e conflito, mas que podem ser perfeitamente superáveis, já que se trata de um debate democrático mediante sucessivos ciclos de construção e aprimoramento. Cumpre-nos compreender, agora, em que medida essa perspectiva de construção de conhecimento se manifesta nos dados da pesquisa.

\section{ConTeXto E DESENVOLVIMENTO DA PESQUisa}

Este trabalho foi desenvolvido privilegiando o enfoque qualitativo, uma vez que a intenção foi discutir as reais possibilidades, impedimentos e dificuldades de interação dialógica entre sujeitos e conhecimentos, no ambiente de aprendizagem do curso de Licenciatura a distância em Pedagogia, ofertado pela Unimontes por meio do Sistema Universidade Aberta do Brasil (UAB). Assim, para possibilitar a análise das discussões no Fórum de Discussão desse curso, utilizamos uma abordagem de análise histórico-dialética, por compreender que esse método permite "buscar as relações concretas e efetivas por trás dos fenômenos" (ZAGO, 2013, online), permitindo identificar as contradições e as dinâmicas do processo de interação dialógica entre sujeitos e conhecimentos nesse espaço.

Para tanto, primeiramente desenvolvemos uma análise descritiva desse curso de graduação e, em seguida, analisamos 285 (duzentas e oitenta e cinco) mensagens que foram postadas em Fórum de duas disciplinas selecionadas para a pesquisa no período de fevereiro a maio de 2018. Com o objetivo de confrontar os dados obtidos para entender a realidade, analisamos, nas mensagens, como as categorias participação, comunicação e colaboração se manifestam entre os agentes das disciplinas, alicerçando o processo de construção do conhecimento.

Para esta pesquisa, selecionamos, em 2018, 2 (duas) disciplinas do curso de Licenciatura em Pedagogia, ofertado pelo Sistema $\mathrm{UAB}$, que foram ministradas no $3^{\circ}$ período do curso. Este período foi selecionado por acharmos que, nele, docentes e discentes já estivessem familiarizados com a educação a distância. As disciplinas selecionadas foram Didática e Estrutura e Funcionamento do Ensino Fundamental e Médio, disciplinas componentes da formação profissional 
dos professores e, por isso, consideradas fundadoras de competências docentes, razão que define tal escolha.

\section{Resultados E Discussão}

A participação no Fórum de Discussão das disciplinas Didática e Estrutura e Funcionamento do Ensino, do curso de Pedagogia, pôde ser assim identificada:

Tabela 1 - Participações no Fórum de Discussão

\begin{tabular}{|c|c|c|c|c|c|}
\hline \multirow[b]{2}{*}{ CURSO } & \multirow{2}{*}{$\begin{array}{c}\mathbf{N}^{\circ} \mathrm{DE} \\
\text { ALUNOS } \\
\text { ATIVOS }\end{array}$} & \multicolumn{2}{|c|}{ DIDÁTICA } & \multicolumn{2}{|c|}{$\begin{array}{c}\text { ESTRUTURA E } \\
\text { FUNCIONAMENTO DO ENSINO }\end{array}$} \\
\hline & & $\mathrm{N}^{\circ}$ de participantes & $\begin{array}{c}\mathbf{N}^{\circ} \mathrm{de} \\
\text { mensagens } \\
\text { postadas }\end{array}$ & $\mathbf{N}^{\circ}$ de participantes & $\begin{array}{c}\mathbf{N}^{\circ} \text { de } \\
\text { mensagens } \\
\text { postadas }\end{array}$ \\
\hline \multirow{2}{*}{ PEDAGOGIA } & \multirow{2}{*}{173} & 85 & \multirow{2}{*}{180} & 29 & \multirow{2}{*}{105} \\
\hline & & $49,3 \%$ & & $16,76 \%$ & \\
\hline
\end{tabular}

Fonte: Elaboração própria (2018).

Após a análise das 285 (duzentas e oitenta e cinco) mensagens postadas nos Fórum por $49,3 \%$ dos participantes da disciplina Didática e por $16,76 \%$ dos participantes da disciplina Estrutura e Funcionamento do Ensino, ministradas no $3^{\circ}$ período do curso de Licenciatura em Pedagogia a distância, ofertado pela Unimontes a partir do Sistema UAB, considerando as categorias participação, colaboração e comunicação, podemos constatar que a complexidade no processo de ensino-aprendizagem na modalidade a distância reside, em grande parte, na interação entre professores, tutores, acadêmicos e TDIC.

Em relação à categoria participação, na disciplina Didática, foram criados 4 Fóruns de discussão, com 1 tópico cada. Entretanto, dos 173 (cento e setenta e tres) alunos ativos, apenas 85 (oitenta de cinco) participaram dos Fóruns. Já na disciplina Estrutura e Funcionamento do Ensino, o índice de participação foi ainda menor, pois foram criados 4 Fóruns, com 2 tópicos cada e somente 29 (vinte e nove) estudantes participaram.

Os professores formadores também participaram pouco: na disciplina Didática, o professor formador participou apenas uma vez, respondendo a um questionamento. Na segunda disciplina, houve 5 (cinco) participações do professor formador, que também apenas respondeu a questionamentos.

Os tutores a distância participaram 4 (quatro) vezes dos Fóruns da disciplina Didática, respondendo com respostas curtas e objetivas e, ainda, em 3 (três) dessas participações, o conteúdo não tinha nenhuma relação com o tema em discussão. Já na disciplina de Estrutura 
e Funcionamento, houve 7 (sete) participações dos tutores a distância, entretanto, apenas responderam ao questionamento dos acadêmicos.

Os tutores presenciais não participaram dos Fóruns da disciplina Didática e participaram com duas mensagens em resposta a acadêmicos em Fóruns da disciplina Estrutura e Funcionamento do Ensino.

Em relação à participação dos acadêmicos, foi identificado que muitos apresentaram respostas contendo apenas reprodução de textos da disciplina ou outros textos. Identificou-se, ainda, que houve ausência de interação, uma vez que somente respondiam ao questionamento proposto, conforme demonstra o quadro 1, que retrata um Fórum da disciplina Estrutura e Funcionamento do Ensino.

Quadro 1- Fórum de Discussão

\begin{tabular}{|c|c|}
\hline \multicolumn{2}{|c|}{ Disciplina: Estrutura e Funcionamento do Ensino Fundamental e Médio } \\
\hline $\begin{array}{c}\text { Por M. O. B. S (P F)- Tuesday, } 23 \text { February } 2018 \text {, } \\
\text { 08:35 }\end{array}$ & $\begin{array}{l}\text { Responda o que você pensa sobre as questões abaixo: } \\
\text { * Para a LDBEN 9394/96 (Lei de Diretrizes e Bases da } \\
\text { Educação Nacional) qual deve ser o objetivo principal } \\
\text { para a educação básica brasileira? } \\
\text { *A LDB (Lei de Diretrizes e Bases da Educação } \\
\text { Nacional) 9394/96 propôs um ensino fundamental } \\
\text { de maior duração. Podemos afirmar que isso é um } \\
\text { desafio para os nossos líderes educacionais. E qualé a } \\
\text { extensão deste desafio para a sociedade? }\end{array}$ \\
\hline $\begin{array}{c}\text { Por A. P. R. F. ( T D) - Tuesday, } 23 \text { February 2018, } \\
\text { 09:12 }\end{array}$ & $\begin{array}{l}\text { Caros acadêmicos! } \\
\text { Estamos aguardando a participação de vocês neste } \\
\text { fórum. Enriqueçam este espaço com suas idéias. } \\
\text { Abraços, }\end{array}$ \\
\hline $\begin{array}{l}\text { Por J. F. S. (Acadêmico) Sunday, } 7 \text { March 2018, } \\
\text { 19:56 }\end{array}$ & $\begin{array}{l}\text { A LDB - 9394/96 foi baseada no princípio do direito } \\
\text { universal que rege a educação para todos, bem como } \\
\text { uma série de mudanças voltadas para a garantia } \\
\text { da educação básica, buscando a promoção de uma } \\
\text { educação de qualidade para todos. Um país para } \\
\text { se evoluir necessita de uma educação de qualidade } \\
\text { como um dos principais pontos de partida, fato esse } \\
\text { considerado meio que distante da realidade brasileira. } \\
\text { Apesar disso, o Governo Federal, com o objetivo de } \\
\text { melhorar a educação no Brasil, criou o PDE (Plano } \\
\text { de Desenvolvimento da Educação), cuja finalidade } \\
\text { é oferecer educação básica de qualidade a todos os } \\
\text { indivíduos, realizando investimentos na educação } \\
\text { profissional e superior, visto que apresentam uma } \\
\text { relação intima, envolvendo um trabalho em conjunto, } \\
\text { no qual pais, alunos, professores e gestores visemo }\end{array}$ \\
\hline
\end{tabular}


continuação

\section{Disciplina: Estrutura e Funcionamento do Ensino Fundamental e Médio}

Por J. F. S. (Acadêmico) Sunday, 7 March 2018, 19:56

sucesso e a permanência do aluno na escola. Um país não progride com uma educação precária, todas as pessoas necessitam e devem ter acesso à, no mínimo, educação básica.

Por M. O. B. S. (PF) - Tuesday, 9 March 2018, 08:41

ok J. F. S as suas colocações estão corretas. Agora estude sobre o ensino de o9 anos e responda a questão apresentada.

Por A. P. O. (TP)- Tuesday, 23 February 2018, 09:39

É isso aí A. P. R. F. Vamos participar acadêmicos... Abraços... O tempo está passando... onde estão vocês acadêmicos de São João da Ponte???

Por A. L. M.F. (T D) - Wednesday, 24 February 2018, 08:28

Abraços,

Por A. C.M. (T P)-Wednesday, 3 March 2018, 15:00

Aguardamos a participação de vocês, acadêmicos de São João da Ponte.

Abraços,

Por S. A. F.(Acadêmica)- Wednesday, 3 March Olá professora, 2018, 17:05

A LDB - 9394/96 (Lei de Diretrizes e Base) foi baseada no princípio do direito universal que rege a educação para todos, bem como uma série de mudanças voltadas para a garantia da educação básica, buscando a promoção de uma educação de qualidade para todos. Um país para se evoluir necessita de uma educação de qualidade como um dos principais pontos de partida, fato esse considerado meio que distante da realidade brasileira. Apesar disso, o Governo Federal, como objetivo de melhorar a educação no Brasil, criou o PDE (Plano de Desenvolvimento da Educação), cuja finalidade é oferecer educação básica de qualidade a todos os indivíduos, realizando investimentos na educação profissional e superior, visto que apresentam uma relação intima, envolvendo um trabalho em conjunto, no qual pais, alunos, professores e gestores visem o sucesso e a permanência do aluno na escola. Um país não progride com uma educação precária, todas as pessoas necessitam e devem ter acesso à, no mínimo, educação básica. A aprovação da LDB (Lei de Diretrizes e Bases da Educação) propiciou grande avanço no sistema de educação de nosso país, visando que a escola se torne um espaço de participação social, valorizando a democracia, o respeito, a pluralidade cultural e a formação do cidadão, dando mais vida e significado para os estudantes. 
conclusão

\begin{tabular}{|c|c|}
\hline \multicolumn{2}{|c|}{ Disciplina: Estrutura e Funcionamento do Ensino Fundamental e Médio } \\
\hline Por M. O. B. S. ( PF)- Wednesday, 3 March 2018, \\
$18: 27$ & $\begin{array}{c}\text { Muito bem S, a sua resposta está corretíssima. A LDB } \\
\text { de } 96 \text { trouxe um novo olhar a educação brasileira, mas } \\
\text { ainda temos que avançar muito. Como você mesma } \\
\text { disse não basta somente uma lei, ela é o principio, mas } \\
\text { é preciso vontade política e organização da sociedade } \\
\text { para que o que está proposto na lei se torne realidade. } \\
\text { Parabéns pelas colocaçôes. Profa. O. }\end{array}$ \\
\hline
\end{tabular}

Figura 1: Fórum da Unidade III da disciplina Estrutura e Funcionamento do Ensino Fonte: Ambiente Virtual de Aprendizagem - Unimontes - Elaboração própria (2018)

Neste Fórum, é possível observar os apelos do professor formador, tutor presencial e tutor a distância para que os alunos participassem. Ainda é possível observar que os alunos que participaram, de fato, apenas postaram trechos de textos, pois as duas respostas mostram o mesmo texto da LDB - 9394/96 (Lei de Diretrizes e Bases da Educação Nacional), baseada no princípio do direito universal.

Contudo, o Projeto Político Pedagógico (2008, p. 22) do curso assinala que:

A relação dialógica, base da comunidade de aprendizagem, seja presencial ou mediada pelas tecnologias, deverá ser exercício permanentemente praticado por todos os participantes, num processo de desenvolvimento capaz de conduzir os diferentes sujeitos aprendizes a uma unidade de ação, tornando-os engajados na tessitura desta rede real e virtual de todos os envolvidos no curso (UNIMONTES, 2008, p. 22).

Nessa perspectiva, o próprio documento reconhece que a relação dialógica é a base da aprendizagem e que deve ser praticado permanentemente. Porém, a presente pesquisa demonstra a ausência de interação no ambiente virtual de aprendizagem e, consequentemente, de relação dialógica.

Assim, em relação à categoria participação, os dados revelam que os alunos participaram dos Fóruns apenas respondendo com textos alheios aos questionamentos propostos pelo professor formador e/ou tutor a distância, podendo indicar que os sujeitos foram em sua maioria passivos. Esse comportamento pode estar relacionado ao modo de participação dos professores formadores, que teriam a função de incentivar a comunicação opinativa, promover a participação e a colaboração, de modo a possibilitar a efetiva construção do conhecimento.

Contudo, as análises demonstram que a participação dos professores formadores se restringiu a postar questões iniciais nos Fóruns, sem retornar para discutir, acompanhar ou orientar os acadêmicos, ficando estas atividades sob a responsabilidade dos tutores a distância. Logo, os acadêmicos participaram, em grande parte, dos Fóruns de Discussão das 
disciplinas, somente respondendo objetivamente aos questionamentos. Na maioria das vezes, não havia fomento à participação, pois os professores não retornavam para dar continuidade e aprofundamento às discussões, tampouco discutiam questões relacionadas ao processo ensino-aprendizagem.

Em relação à categoria comunicação, as análises sugerem que o design e a dinâmica da participação de professores e alunos na disciplina repercutem decisivamente nos processos de comunicação, uma vez que a comunicação é derivada do modelo de participação. Partindo do pressuposto defendido por Freire (2013) de que, na comunicação dialógica, não haveria sujeitos passivos, mas sim coparticipação e reciprocidade, observamos, por meio da maioria das mensagens, uma postura que pode ser considerada passiva por parte dos participantes, que se limitavam a responder objetivamente questionamentos propostos pelo professor, sem indicar continuidade responsiva ou travar diálogos com outros participantes. Isso indica fissuras na estrutura dos processos comunicacionais das disciplinas, segundo a visão freireana, o que repercutirá, sem dúvida, na construção de conhecimentos.

Lembramos que, segundo Freire (2013), a comunicação verdadeira não se estabelece por meio da transferência ou transmissão de conhecimento de um sujeito a outro, mas se erige por meio da troca e da co-construção dos processos de significação.

A categoria colaboração, por sua vez, se revelou altamente dependente dos processos de participação e comunicação, uma vez que a colaboração se concretiza por meio de comunicação, que, por sua vez, se especifica a partir do modelo de participação construído. Assim, considerando o princípio defendido por Almeida (2001) de que o homem apreende a realidade por meio de uma rede de colaboração na qual cada ser ajuda o outro a se desenvolver, ao mesmo tempo em que também se desenvolve, constatamos, nos Fóruns, ausência de incentivo para estimular os acadêmicos a aprenderem com o outro e por meio do outro, seja continuando, refutando ou endossando a reflexão do colega, seja direcionando seus próprios comentários ao grupo. Os dados nos revelam, portanto, participações estanques, com início e término em si mesmas, que não se deixam permear pela subjetividade alheia, o que impede o desenvolvimento de processos colaborativos.

Considerando que somente $49,3 \%$ dos acadêmicos participaram do Fórum da disciplina Didática e 16,76\% do Fórum da disciplina Estrutura e Funcionamento do Ensino, sendo um número muito pequeno se comparado ao ideal da democracia rousseauniana que abarca toda a coletividade e a experiência dos pesquisadores com esse curso, identificamos alguns fatores que dificultaram a participação dos acadêmicos nos Fóruns.

O primeiro fator que pode ter dificultado principalmente a democratização do ciberespaço é a dificuldade do acesso à internet. A maioria dos alunos dos cursos de licenciatura da UAB/ Unimontes não possui acesso à internet em casa e utiliza laboratórios de informática conectados à internet dos polos de apoio presencial. Como os polos são de responsabilidade das Prefeituras Municipais, é comum a internet não funcionar, o link ser de baixa velocidade ou o laboratório 
atender a um grande número de alunos, sem contar que muitos acadêmicos residem em comunidades rurais distantes dos polos e que só vão ao polo durante as atividades presenciais.

O segundo fator que dificulta a realização das atividades no ambiente virtual de aprendizagem é a falta de domínio do computador. Apesar de estarem matriculados em um curso de licenciatura a distância, mediatizado pelas TDIC, muitos alunos não têm domínio dessa ferramenta e utilizam o computador somente no Polo para realizar as avaliações online (AO).

Sendo o diálogo a base da democracia, Freire (2013) afirma que é necessário incentivar a expressão e a participação efetiva de todos no poder. Assim, o diálogo, como exigência radical da democracia, responde a outra exigência radical: o direito e acesso à comunicação. Nessa perspectiva, não ter acesso à tecnologia que media a comunicação contribui para a exclusão social e enfraquece a perspectiva democrática da educação nas circunstâncias descritas.

O terceiro e principal fator, a nosso ver, que dificultou a democratização e a interação dialógica neste espaço, foi o fator cultural. Debater, discutir, tornar o diálogo possível entre os participantes parece não fazer parte da cultura dessa comunidade acadêmica. Ainda estamos presos ao modelo unidirecional de comunicação, de um para muitos, transportando, para sala de aula virtual, o modelo de comunicação centrado no professor para os alunos. Isso ficou visível nas mensagens dos Fóruns de Discussão em que os acadêmicos se restrigiam, via de regra, a responder as questões apresentadas pelos tutores e professores formadores. Os acadêmicos dialogavam, na maioria das vezes, com o tutor e não com os outros cursistas. A impressão que se tinha é a de que cumpriam ali uma exigência burocrática, sem o engajamento que se precisa para se construir conhecimentos numa perspectiva dialógica.

Partindo da afirmação de Freire (2013b) de que significado é trabalho, práxis, ação de transformar o mundo, e que por isso, ninguém produz significado sozinho, constatamos que o projeto pedagógico do curso selecionado, ao utilizar o Fórum como um espaço de interação, teve a intenção também de possibilitar o encontro entre os participantes. Porém, como demonstra a tabela 1, 50,7\% "não compareceram ao encontro" de Didática e 83,24\% ao de Estrutura e Funcionamento do Ensino. Ao se ausentarem das discussões, tornam-se impermeáveis à contribuição do outro e indolentes à própria reelaboração de si que acontece no confronto com o outro. Notadamente, aspectos socioeconômicos e culturais estão na base desse acontecimento. Como ensina Freire (2013b), não é possível o diálogo entre os que querem a pronúncia do mundo, os que não a querem e os que não têm condições por limitações sócioeconômicas. Para que o diálogo se realize, é preciso, primeiro, que todos conquistem as condições básicas.

Analisando a estrutura do curso, observamos que, apesar do esforço da equipe responsável por sua elaboração, principalmente no que se refere às possibilidades de interação entre os envolvidos, o foco ainda se centrou na transmissão de informações, assentando o curso no modelo de educação bancária tão criticado por Freire (2013b). Isso pode ser percebido por meio de processos de comunicação que se efetivam em um caráter, muitas vezes, linear e monológico, em que o emissor se restringe a indicar um comando a ser realizado 
silentemente pelo receptor. Assim, o diálogo se restringe a um discurso de efeito monológico, pronto e unilateral, não existindo espaço de interação para a co-construção, e a língua passa, assim, a ser um instrumento de reprodução do sistema vigente. As análises comprovam que, nas escassas vezes em que os acadêmicos eram incentivados a se posicionarem, emitirem sua opinião sobre o tema estudado, isso só ocorria após o professor formador emitir sua palavra e postar a questão que deveria ser discutida, exercendo uma força centrípeta sobre os discursos (BAKHTIN, 2006), de forma que os alunos não eram incentivados e desafiados a buscarem o que deveria ser discutido.

Nessa perspectiva, embora o curso tente criar espaços para a discussão, o emissor solicita a opinião, mas não incentiva o diálogo, no sentido de uma constante interação ação/ reflexão, de incentivo a expressão, de participação de todos os envolvidos, em busca da transformação da realidade.

Acreditamos que esta questão ultrapasse os limites desta pesquisa e indique, de modo geral, em maior ou menor grau, um modo de se fazer educação a distância agenciada na unidirecionalidade da comunicação, o que nos leva a concluir que, apesar de a Educação Aberta e a Distância ser um avanço em muitos sentidos, as práticas ainda são convencionais. O diálogo ainda é centrado no professor e/ou no tutor como emissor, restando ao aluno o papel de receptor. Dessa maneira, reproduzimos no virtual, com uma nova roupagem, práticas convencionais e ultrapassadas, que se centram no papel ativo do professor.

A nosso ver, um projeto de Educação Aberta e a Distância salutar deveria fazer germinar um contato frequente e um diálogo intenso, contínuo e inconcluso entre os participantes. A utilização da tecnologia deveria buscar reduzir a distância entre os atores, favorecer a interatividade entre os envolvidos, possibilitar a comunicação profícua entre todos no processo de ensino-aprendizagem, propiciando a motivação, o diálogo e a interação entre os agentes, favorecendo o acesso, a troca e a construção de conhecimento.

Observamos, por fim, que, nos Fóruns de Discussão analisados, não houve complexidade de interação e não surgiram conflitos. As mensagens postadas não revelaram construções dialógicas coletivas. Emissor e receptor não fizeram parte de um processo de relações interligadas por fios dialógicos que trocam, completam, refutam, perguntam, respondem em um processo dinâmico de construção e desconstrução entre os diferentes, criando redes colaborativas de aprendizagem. As poucas trocas observadas foram somente entre os que, de certa forma, partilhavam pensamentos e sentimentos semelhantes. Talvez os que pensavam diferente optaram por não participar para não se comprometerem ou não tiveram acesso, ou simplesmente desconhecem a importância do contraditório e da interação dialógica no processo de construção do conhecimento. 


\section{CoNSIDERAÇõES FINAIS}

Embora a Educação Aberta e a Distância represente, sem dúvida, uma importante conquista no cenário educacional brasileiro, é preciso questionar quais são as premissas que sustentam os modelos interacionais privilegiados nessa modalidade de educação. Tudo indica que há ainda um caminho considerável a ser percorrido para se implementar práticas de fato democráticas e dialógicas no ciberespaço da educação.

A nosso ver, para que a educação online atinja objetivos libertários como os defendidos por Paulo Freire (2013a), será preciso ampliar as vozes dos sujeitos envolvidos, ultrapassando o limiar da oferta de informações e possibilitando a emergência da coconstrução de conhecimentos por meio da troca, da complementação, do endosso e da refutação.

Para tanto, coadunando com Moraes, Fiorentini e Dias (2003), é necessário redimensionar o processo de comunicação, buscando a superação da unidirecionalidade da mensagem, modificando os papéis de emissores e receptores para que passem a ser co-autores/criadores. Isso significa tratar o conhecimento como coconstruído no curso da interação, incentivando, de um lado, os estudantes a se posicionarem, seja endossando, seja refutando, propondo ou avaliando criticamente a coconstrução e, de outro, levando os professores a se conceberem como agentes mediadores e possibilitadores desse processo, tornando-se gestores de um ambiente de interção que usa a tecnologia para promover valores fundamentalmente humanos, por meio da interação dialógica.

Assim, pesquisas sobre a qualidade das interações na Educação Aberta e a Distância e sobre o redimensionamento do processo de comunicação que vise à dialogicidade da comunicação se mostram, atualmente, bastante promissores, por contribuírem para o aperfeiçoamento das práticas.

\section{REFERÊNCIAS}

AGUIAR, Ilmar Duarte Fonseca. A formação de professor a distância pelo sistema UAB/ Unimontes: um estudo sobre a construção do conhecimento no curso de pedagogia. 2014. 62f. Monografia (Graduação) - Curso de Pedagogia, Centro de Ciências Humanas, Unimontes, 2014. ALMEIDA, M. E. B. Tecnologia na escola: criação de redes de conhecimentos. Boletim do Salto para o Futuro-TVE. MEC/SEED/TV Escola, 2001. Disponível em: www.tvebrasil.com.br/salto/ tec/tectext2.htm. Acesso em: 8 mar. 2002.

ARAÚJO. A. C. Gestão democrática da educação: a posição dos docentes. 2000. 220 f. Dissertação (Mestrado em Educação). Programa de Pós-Graduação em Educação. Universidade de Brasília, Brasília, 2000.

BELLONI, M. L. Educação a distância. 7. ed. Campinas, SP: Autores Associados, 2015. 
BOBBIO, N. Liberalismo e democracia. Tradução de Marco Aurélio Nogueira. São Paulo: Edipro, 2017.

CASTORIADIS, C. As encruzilhadas do labirinto, III: o mundo fragmentado. Rio de Janeiro: Paz e Terra, 1992.

FREIRE, P. Pedagogia do oprimido. 67. ed. Rio de Janeiro: Paz e Terra, 2013a.

FREIRE, P. Extensão ou comunicação? Tradução de Rosilka Darcy de Oliveira. Rio de Janeiro: Paz e Terra, 2013b.

GUR-ZE’EV, I. É possível uma educação crítica no ciberespaço? Comunicações. Caderno do Programa de Pós Graduação em Educação. São Paulo. V. 9, n. 1, 2002. Disponível em: https:// www.metodista.br/revistas/revistas-unimep/index.php/comunicacoes/article/view/1570. Acesso em: 18 maio 2020.

KELLNER, D. Novas tecnologias, novas alfabetizações: reconstruindo a educação para o novo milênio. Educação e Sociedade, Campinas, v. 29, n. 104. out. 2008. Disponível em: https:// www.scielo.br/scielo.php?script=sci_arttext\&pid=S0101-73302008000300004. Acesso em: 5 ago. 2018.

LÉVY, P. As tecnologias da inteligência: o futuro do pensamento na era da informática. 2. ed. Rio de Janeiro: Ed. 34, 2010.

MORAES, R. de A. Novas tecnologias, educação e gestão. A Página da Educação. Portugal, Ano 10, n. 99, fev. 2002, p. 14.

MORAES, R. de A.; FIORENTINI, L. M.; DIAS, Â. C. Interatividade em EAD. Rio de Janeiro: DP\&A, 2003.

PERRENOUD, P. Dez novas competências para ensinar. Porto Alegre: Artes Médicas Sul, 2000.

PETERS. M. Pós-estruturalismo e filosofia da diferença. Belo Horizonte: Autêntica, 2000.

PONTES. E. Ambientes virtuais de aprendizagem cooperativa. In: Workshop Internacional sobre Educação Virtual. - ANAIS. NECAD/UECE. Fortaleza: 1999, 412.

PRIMO. A.; CASSOL. M. B. F. Explorando o conceito de interatividade: definições e taxonomias. Informática na educação: teoria e prática, v. 2, n. 2, 1999. Disponível em: https://seer.ufrgs. br/InfEducTeoriaPratica/article/view/6286. Acesso em: 5 ago. 2018.

SERRÃO, R. M. R. Por entre as telas, um espaço de aprendizagem. 2001. $136 \mathrm{f}$. Dissertação (Mestrado em Educação). Programa de Mestrado em Educação. Universidade de Brasília, Brasília, 2001.

SOARES, D. Revolução cibernética na comunicação e ilusão democrática. Portal de e-governo, inclusão digital e sociedade do conhecimento. Disponível em: https://egov.ufsc.br/portal/ conteudo/revolu\%C3\%A7\%C3\%A30-cibern\%C3\%A9tica-na-comunica\%C3\%A7\%C3\%A3o-eilus\%C3\%A30-democr\%C3\%Artica. Acesso em: 5 nov. 2017. 
TOURAINE, A. O que é democracia? 2. ed. Rio de Janeiro: Vozes, 2007.

UNIMONTES. Coordenadoria de Educação a Distância. Projeto Pedagógico Curso de Pedagogia Licenciatura UAB. Universidade Estadual de Montes Claros, 2008.

VIEIRA, Fábia Magali Santos. Ciberespaço e Educação: possibilidades e limites da interação dialógica nos cursos online da unimontes virtual. 2003. $128 \mathrm{f}$. Dissertação (Mestrado em Educação), Programa de Pós-graduação em Educação, Universidade de Brasilia, Brasilia, 2003. VYGOTSKY. L. S. Pensamento e linguagem. 4. ed. São Paulo: Martins Fontes, 2008.

Recebido para publicação em: 3 jun. 2020. Aceito para publicação em: 16 set. 2020. 